\title{
Tien eeue leksikografie: Van woordelys tot woordeboek
}

\author{
Wouter C van Wyk
}

\section{Abstract}

Ten centuries of lexicography: From vocabulary list to dictionary

The aim of the article is to illuminate the development in the lexicography of Biblical Hebrew through ten centuries from the first vocabularly list to a dictionary based on linguistic, comparative Semitic and encyclopedic principles. The writer treats several stages through the Middle Ages, the Reformation period, the Enlightenment and the Twentieth century up to a contemporary project of South African scholars working on a new Semantic Hebrew 'wordbook'. The conclusion in the article is that the nature of a specific dictionary or vocabularly list, for example philological, theological or linguistic, serves particular, legitimate needs.

Professor Van Selms het nooit prinsipiële besinnings oor die leksikografie gepubliseer of daaroor as 'n subdissipline van die Semitistiek gedoseer nie, maar vanaf sy proefskrif oor 'De Babylonische termini voor zonde en hun betekenis voor onze kennis van het Babylonische zondebesef' in 1933 tot by sy laaste Job-kommentare in 1982 en 1983 het hy 'n reuse-bydrae tot die leksikons van die Semitiese Tale gelewer. 'n Artikel in die Journal of North West Semitic Literature III, 1974 getitel 'The etymology of yayin "wine"' en in Ugaritforschungen, Band II, 1979 oor 'The root $k-t-r$ and its derivatives in Ugaritic literature' is enkele voorbeelde waar Van Selms afsonderlike artikels oor woorde en hulle betekenisse geskryf het. Sy grootste bydrae op hierdie terrein lê egter in sy kommentare op die Ou Testament. Sy uitleg het altyd uitgegaan van die Bybelse teks en dié teks bestaan uit woorde in konteks. Dat hy veral geïnteresseerd was in die etimologie van 'n woord, 'n opsig waarin hy as wetenskaplike volledig kind van sy tyd was, het nie van hom 'n etimologis gemaak nie, want in lesings en in geskrifte het hy altyd die beginsel beklemtoon: verba valent $u s u$, 'woorde het hulle betekenisse deur hulle gebruik'.

Ons kan verskillende tipes Ou-Testamentiese woordeboeke onderskei. In hierdie kort oorsig kan daar van volledigheid nie sprake wees nie. Dit wil voorkom of hierdie tipes ook in 'n historiese ontwikkelingslyn lê.

Die eerste stadium is dié van eenvoudige woordelyste of glossaria. Die oudste Hebreeuse woordeboek waarvan ons weet, is afkomstig van 
Saadya die Gaon van Sura (892-942) (Waxman 1960: 166vv). Dit heet Agron 'woordelys' en die eerste uitgawe daarvan het hy op twintigjarige leeftyd geskrywe. Dit was egter net 'n eentalige woordelys in twee dele: in die eerste deel was die woorde gerangskik volgens die beginletters en in die tweede deel volgens die slotletters. Die doel van die woordelys was om digters met hulle rym behulpsaam te wees. In 'n Hebreeuse inleiding is die geskiedenis van die Hebreeuse taal beskrywe. Hierdie eerste uitgawe is gevolg deur 'n tweede uitgebreide uitgawe wat van 'n Arabiese inleiding en Arabiese vertaalekwivalente voorsien is. Die inleiding is interessant omdat dit die konsonante in twee klasse indeel, naamlik dié konsonante wat slegs as stamkonsonante gebruik is, en die ander helfte wat sowel stamkonsonante en preformatiewe of afformatiewe kon wees. Daarmee is erkenning verleen aan die bestaan van stamme (wortels) en pre- en afformatiewe as konstituerende elemente van die Hebreeuse taal. Hierdie werk van Saadya het net gedeeltelik bewaar gebly. Dit was die eerste Hebreeuse 'woordeboek' wat vertaling ('betekenisse') aangebied het, waarvan ons bewus is. Dit was egter nie uitsluitlik 'n Ou-Testamentiese woordelys nie, maar het ook Hebreeuse woorde van die Misjna bevat. Dit is belangrik om daarop te let dat die leksikografiese werk van Saadya saamgehang het met sy grammatikale insigte en ook uitgeloop het op die skrywe van die eerste Hebreeuse grammatika, geskryf in die Arabiese taal.

Van groter betekenis vir die ontwikkeling van die Ou-Testamentiese leksikografie was sy derde leksikografiese werk. Dit het 'n lys van 90 $\mathrm{Ou}$-Testamentiese woorde bevat wat of hapax legomena was of selde in die Ou Testament voorgekom het. Hy gee nie alleen die 'teksverwysings' vir hierdie woorde nie, maar verklaar hulle ook na aanleiding van die betekenis van verwante woorde in die Misjna en Talmoed. Hiermee word die noue verwantskap tussen die Bybelse en die Na-Bybelse Hebreeus aangetoon, asook tussen Hebreeus en Aramees. Die werk het volledig bewaar gebly.

Kyk ons nou samevattend na Saadya se leksikografiese werk, merk ons op dat die volgende elemente oor die eeue heen 'n deel van die leksikografiese tradisie gebly het: Die rangskikking in alfabetiese volgorde; die onderskeiding in stamme en grammatikale elemente, al is dit net in die inleiding van sy werk; die aangee van vertaalekwivalente in die algemene taal van die nabye Ooste gedurende die Middeleeue, naamlik Arabies ('n tweetalige woordelys dus in die tweede uitgawe van sy Agron) en die vroegste gebruikmaking van 'n vergelykende 
Semitiese taalkunde, al was dit op 'n baie elementêre vlak. Die betekenis van sy vergelykings met die Misjna kom skerper na vore as ' $n$ mens dink aan die voortreflike bydrae van Kutscher op die gebied van die sogenaamde Middel-Hebreeus tot die hersiene uitgawe van die woordeboek van Koehler-Baumgartner. ' $n$ Geleerde soos Barr ag die aangee van die verwante Misjna-woorde as aanduiding van die 'boundaries of Old Testament meanings' 'n onontbeerlike bestanddeel van 'n Ou Testament-woordeboek.

Noord-Afrika het ook ander leksikografiese pioniers opgelewer. Aan Juda ibn Koreish word die begin van vergelykende taalkunde toegeskryf. In sy 'die boek van verwantskap' (Sefer ha-Yahas) het hy lyste van Hebreeuse woorde gepubliseer wat respektiewelik met Aramees en Arabies verwantskap gehad het. Van 'n groter woordeboek wat hy sou geskryf het, het niks bewaar gebly nie. Ook uit die 10de eeu kom Dunash ben Tamin (900-960) van Kairawan in Noord-Afrika wat die enge verwantskap van Hebreeus met Arabies aangetoon het.

Die eer kom egter 'n Spaanse Jood, Menahem ben Saruk, toe as skepper van die eerste woordeboek wat in Hebreeus geskryf is waarin die hele Ou-Testamentiese woordeskat gedek word. Dit heet Mahberet 'samevoeging (van woorde)'. In die inleiding word ook baie aandag aan grammatikale kwessies gewy. Hy deel die Hebreeuse konsonante in dieselfde twee klasse as Saadya in. Hy het verder geglo dat Hebreeuse stamme van een tot vyf stamkonsonante kon bevat. Hy was skepper van die term medaqdeq vir die 'grammatikus', 'n woord waaruit die bekende term diqduq as aanduiding van 'grammatika' ontwikkel het. Deur sy afleiding van naamwoorde uit werkwoorde het hy baie bygedra tot die vasstel van werkwoordstamme. Aramees en die Hebreeus van die Misjna is gebruik om die betekenis van die Ou-Testamentiese woorde te verklaar.

Ons sluit hierdie oorsig oor die begin van die Ou-Testamentiese leksikografie af met drie verwysings: eerstens na Dunash ben Labrat wat teen Menahem en Saadya gepolemiseer het en in 'n gedig(!) op 160 foute in die werk van Menahem ten opsigte van woordverklaring en -afleiding gewys het. Hy was die eerste wat die Hebreeuse stamme na die voorbeeld van die Hebreeuse werkwoord pa'al aangedui het, ' $n$ gebruik wat tot vandag toe lewend en sinvol gebly het. Die ongunstige resensie van die Mahberet deur Dunash het geleerdes in twee kampe gedryf, 'n pro- en 'n anti-Menahem, met strydskrifte oor en weer tussen die volgelinge van die twee leiers. Tog het die Mahberet sy aansien behou en baie lank die belangrikste leksikale hulpmiddel by die studie 
van die Bybel in nie-Arabies sprekende lande gebly (Jones 1963: 524). Ons tweede verwysing is na Jona ibn Janah (990-1050) wat ook as Abu al-Walid Mervan bekend gestaan het. Hy was medikus van beroep, maar sy begeerte om die Bybel te verstaan, het hom daartoe gebring om hom op die studie van die Hebreeuse taal toe te lê. In Saragossa het hy sy meesterwerk oor die Hebreeuse taal en woordeskat die lig laat sien, Al-Tankikh 'die boek van die kritiek', 'n kritiese bestudering van die Hebreeuse taal. Die tweede deel was die woordeboek, die Kitab al-Usul 'die boek van die radikale (stamme, wortels)'. Sommige geleerdes beskou dit as die toppunt van die leksikografie van die Middeleeue (DR Jones 1963: 524). Dit munt in twee opsigte bo die werk van sy voorgangers uit: Dit maak meer as ooit tevore van Arabies gebruik om betekenisse vir onbekende Bybelse woorde vas te stel, maar belangriker nog: vir elke stam gee hy betekenisskakerings aan wat hy met behulp van voorbeelde illustreer (Waxman 1960: 174). Deur Juda ibn Tibbon is dit uit Arabies in Hebreeus vertaal en dit het invloed op alle latere woordeboeke uitgeoefen. Naas die genoemde Spaanse taalgeleerdes was daar 'n hele paar geringer figure wat almal bydraes tot die Hebreeuse grammatika en die leksikografie gemaak het. Die bekende grammatikus en Bybelkommentator, Abraham ibn Esra het hier ook ' $n$ bydrae gelewer, maar sover dit die leksikografie aangaan, was dit meer indirek deur middel van 'n leerling van hom, Salomo ibn Parhon wat ook 'n woordeboek laat verskyn het. Die groot betekenis van Ibn Esra is egter daarin geleë dat hy 'n soort van wandelende professor was wat in verskillende dele van Europa gewerk en opgetree het, onder andere in Rome en in die sogenaamde Provence in Frankryk. Hoewel die reedsgenoemde Juda ibn Tibbon 'n Spanjaard was, gebore in Granada, het hy hom in Lunel gaan vestig, waar hy Ibn Janah se leksikon vertaal het. Deur sy werksaamhede hier in die suide van Frankryk het hy die werk van ibn Janah, en by name 'Die boek van die radikale' aan die Hebreeus-lesende Jode van Wes-Europa bekend gestel. In Narbonne, ' $n$ ander stad in die Provence, was daar die bekende Kimhi-familie wat vir twee generasies lank die terrein van die grammatika en die leksikografie oorheers het. Bekende figure van die Kimhi-familie was Josef en sy twee seuns, Moses en Dawid. Die grootste van die drie was ongetwyfeld Dawid (1160-1235). Hy het op verskillende terreine uitgemunt op die gebied van die grammatika en op die gebied van die leksikografie. Hy het op die voetspoer van Ibn Janah 'n grammatika en 'n woordeboek geskrywe. Hy het die woordeboek Sefer ha-Shorashim genoem wat die Hebreeuse weergawe is van die 
titel van die boek wat deur Ibn Janah geskryt is. Hoewel die titel duidelik op die verband tussen sy werk en dié van Ibn Janah wys, was dit ' $n$ selfstandige werk. By elke inskrywing van ' $n$ bepaalde stam is alle vorms van die werkwoord gegee, sowel as die afleidings daarvan, naamwoorde en adjektiewe, en as hy dit nodig geag het, ook kort stukkies eksegetiese kommentaar oor Bybelse gedeeltes waarin 'n bepaalde vorm van die stam voorgekom het. Sover dit die Middeleeue aangaan, was die werk van Dawid Kimhi die hoogtepunt in Hebreeuse grammatika en leksikografie.

Samevattend kan ons dus sê dat daar in die twaalfde eeu, behalwe in Spanje, ook in die Provence in Suid-Frankryk groot literêre aktiwiteit was, veral op die terrein van die Bybel-eksegese, en die Hebreeuse grammatika en leksikografie. Die geleerdes wat uit Spanje geëmigreer het en hulle gevestig het in die verskillende stede van die Provence, het as middelaars opgetree tussen die kulture van die Ooste en die Weste. Spanje was Moslems, en Arabies was die voertaal, maar hierdie Spaanse geleerdes wat ook Hebreeus goed geken het, het vir julle Joodse broers in Frankryk die skatte van Joodse kennis wat in Arabiese werke bewaar is, oopgesluit deur dit in Hebreeus te vertaal. Frankryk het dan ook uiteindelik die leierskap in Hebreeuse geleerdheid van Spanje oorgeneem.

Die werk van Dawid Kimhi, Sefer ha-Shorashim was vir eeue die standaardwoordeboek in Europa. Na die uitvinding van die boekdrukkuns het dit kort voor 1480 in Italië in druk verskyn. Dit is teen hierdie agtergrond dat ons nou daartoe oorgaan om te gaan kyk na wat die stand van sake was in die sestiende eeu, die tyd van die kerkhervorming. Deur die impulse van die reformatore is daar teruggegryp na die oorspronklike bronne van die Bybel, naamlik die Hebreeuse teks van die Ou Testament en die Griekse teks van die Nuwe Testament. Protestantse geleerdes het hulle toegelê op die studie van die Hebreeuse taal, spesifiek die taal van die Ou Testament. Aan Joodse kant is die aandag weer eensydig beperk gewees tot die Hebreeus en die Aramees van die Babiloniese Talmoed. Tussen die jare 1500 en 1800 het daar minstens sewentig woordeboeke die lig gesien. Hoewel hierdie teruggaan na die bronne, in die geval van ons onderwerp spesifiek die Hebreeuse taal en die Hebreeuse Ou Testament, kenmerk van die reformasie was, was dit nie gees van die humanisme en die uitvinding van die boekdrukkuns wat eintlik die groot bydrae gelewer het tot die studie van die $\mathrm{He}$ breeuse taal. Veral drie gedrukte uitgawes van die Hebreeuse Bybel het bygedra tot die bestudering van die Hebreeuse teks, naamlik die Bybel 
van Daniël Bomberg (Venesië 1518), die van Jakob ibn Hajyyim (1521, 1525), en die Koninklike Poliglot van Antwerpen (1572). Uit die oogpunt van die leksikografie was die eerste groot Poliglot-Bybel, die sogenaamde Complutensiese Bybel van 1515, die belangrikste. Sommige beskou dit as die belangrikste Bybelwerk in die sestiende eeu (Kraus 1956: 40). Die sesde volume van die Complutensiese Bybel het die titel gedra Vocabularium Hebraicum et Chaldaicum Veteris Testamenti, geskryf deur ' $n$ bekeerde Spaanse Jood met die naam van Alfonsus Zamorensis. Ander belangrike leksikografiese bydraes uit die sestiende eeu was die werke van Johannes Reuchlin, Rudimenta Linguae Hebraicae una cum Lexico (1506) en Sebastian Münster, Dictionarium Hebraicum (1523).

Die sewentiende en die agtiende eeu is gekenmerk deur die verskyning van poliglottiese of veeltalige woordeboeke. Dit was Albert Schultens (1686-1750) wat die vergelyking van Arabies en Hebreeus op 'n gesonde filologiese basis geplaas het, en daarmee die bodem voorberei het vir toekomstige leksikale studie. Op sy werk het JD Michaelis in sy Supplementa ad lexicon hebraica van 1786 voortgebou. Dit was egter vir Wilhelm Gesenius beskore om tot op die huidige dag beskou te word as die vader van die moderne Hebreeuse leksikografie. Heinrich Friedrich Wilhelm Gesenius (1786-1842) se roem berus op sy omvattende Hebreeuse grammatika, en sy Hebreeuse woordeboek, werke wat in verskillende bewerkings tot op die huidige dag standaardwerke gebly het. Vir elke Semitikus of Ou-Testamentikus is die grammatika en woordeboek van Gesenius, eersgenoemde in die bewerking deur Kautsch en die vertaling van Cowley, en laasgenoemde in die heruitgawe van Buhl, onontbeerlike hulpmiddels by die bestudering van die Hebreeuse teks van die Ou Testament. In sy dae het die dogmatiese teologie byna daarin geslaag om die Hebreeuse taal met sy kettings vas te maak. Hebreeus is beskou as ' $n$ heilige taal. Gesenius is baie sterk beïnvloed deur die rasionalisme van sy eie tyd, en hy het probeer om Hebreeus vry te maak uit hierdie knellende bande. Hy was die eerste geleerde wat die aandag gevestig het op die historiese ontwikkeling van die Hebreeuse taal, en sodoende volledig die gedagte van 'n ahistoriese lingua sacra of 'heilige taal' laat vaar het. In 1910, dieselfde jaar toe hy dosent by die Universiteit van Halle geword het, het hy sy Hebräisch-deutsches Handwörterbuch über die Schriften des Alten Testaments die lig laat sien. Die sewentiende uitgawe van hierdie werk, uitgegee met byvoegings en korreksies deur F Buhl, is steeds 'n standaardwerk waarna met die letters GB verwys word. In 1833 is sy Lexicon 
Manuale Hebraicum et Chaldaicum in Veteris Testamenti Libros gepubliseer. Dit was in Latyn geskryf, en hierdie Latynse handboek is later in Engels vertaal deur Edward Robinson, en uiteindelik het dit die basis gevorm van die baie bekende Brown-Driver-Briggs Hebreeuse en Engelse woordeboek wat in 1907 verskyn het, en tot die huidige dag aan meeste Engelse universiteite gebruik word (BDB). GR Driver het sekere toevoegings en korreksies in 1953 aangebring. Dit is die mees algemeen gebruikte woordeboek in die Engelssprekende wêreld, maar wesenlik is dit die werk van Gesenius. Die Hebreeus-Aramese woordeboek van Julius Fürst wat in 1967 gepubliseer is, was saam met die woordeboek van Gesenius die belangrikste leksikale werke in die negentiende eeu. Ten minste in die Duitssprekende geleerde wêreld het die werk van Gesenius-Buhl tot diep in die twintigste eeu sy posisie gehandhaaf.

In 1953 het die Lexicon in Veteris Testamenti Libros van Ludwig Koehler en Walter Baumgartner verskyn, 'n gebeurtenis van deurslaggewende betekenis op die gebied van die studie van die Ou Testament. Dit was die resultaat van ongeveer veertig jaar se werk, soos Koehler dit self in die inleiding tot sy woordeboek beskrywe. As 'n mens na sy titel kyk, dan kan 'n mens nie anders as om te dink dat hy hierdie woordeboektitel doelbewus gekies het in navolging van die titel van Gesenius se werk nie. In 'n sekere sin het dit die klassieke leksikografiese tradisie van Gesenius soos dit in GB en BDB verteenwoordig is, agterlaat. Koehler het sy woordeboek gebaseer op 'n onafhanlike bestudering van die Hebreeuse teks. Hoewel hy sover as moontlik die opmerkings en argumente van ander geleerdes in aanmerking geneem het, het hy elke stukkie getuienis van vooraf geweeg. In 'n verdere opsig het hy afgewyk van die tradisie deur alle woorde met insluiting van die stamme in alfabetiese volgorde te rangskik. Hoewel die stamme nie woorde in die streng sin van die woord is nie, maak dit wel sin om hulle op die regte alfabetiese plek te rangskik. In GB en in BDB is alle afleidings, byvoorbeeld naamwoorde of adjektiewe, onder die bepaalde stamme of wortels gelys wat in baie gevalle daarop neergekom het dat woorde geplaas is by stamme waarvan dit vermoedelik afgelei is. ' $n$ Goeie voorbeeld hier is die bekende naamwoord ' $\bar{a} b$ wat deur baie geleerdes as 'n primitiewe naamwoord beskou is, met ander woorde een wat nie afgelei is van 'n werkwoord nie. Tog moet 'n mens in hierdie woordeboeke daarna soek onder ' $n$ veronderstelde stam, naamlik die van die werkwoord ' $\bar{a} b \bar{a}$. In sy woordeboek het Koehler besondere aandag aan die volgende aspekte gewy: Volgens hom is die 
hooftaak van die leksikograaf om in moderne taal te vertaal wat ooreenstem met die Hebreeuse woord of frase. Daar bestaan egter ' $n$ lang tradisie van die vertaling van 'n bepaalde woord wat van geslag to geslag oorgelewer is, en op grond waarvan die ou vertalings in Aramees, Grieks en ander tale gedoen is. Die moderne leksikograaf verwerp nie so ' $n$ tradisie sonder meer nie, maar hy aanvaar ook nie die tradisie tensy hy dit geverifieer het nie. By die vertaling van ' $n$ woord word baie noukeurig op die konteks gelet. ' $n$ Woord is alleen dan korrek vertaal as dit verstaanbaar is en in die konteks inpas, maar verder word daar ook gebruik gemaak van die resultate van die vergelykende Semitiese taalkunde. Koehler is hom wel daarvan bewus dat dit met die grootste omsigtigheid gedoen moet word, want as twee woorde in verskillende tale eenders klink, is dit nog nie 'n voldoende rede om hulle betekenisse met mekaar te identifiseer nie. Die groot betekenis van vergelykende Semitiese taalkunde is egter daarin geleë dat dit ondersteunende getuienis bring vir die betekenis van Hebreeuse woorde, en dat dit op parallelle verskynsels in die verskillende tale die aandag vestig. Die gevaar dat 'n mens onkritiese gebruik maak van hierdie vergelykende taal, byvoorbeeld van die besondere ryk woordeskat van Arabies, bly altyd wesenlik. Op die wyse kan allerlei identifikasies en verklarings van betekenisse tot stand kom wat totaal van alle waarheid ontbloot is. Hy werk sterk met die idee van 'n Grundbedeutung. 'It is a principle of modern semantics to differentiate the meaning which is primary, but which is in many cases more restricted, more concrete, from the meanings which have followed later from the primary meaning. The modern principle is to attempt to discover a genetic relation in the development and changes in the meaning of a word, and accordingly to provide a series of meanings established on sound genetic principles. This principle is followed in this dictionary' (Koehler 1953: xiv).

Dit is ongelukkig ' $n$ benadering wat selfs in die derde hersiene uitgawe van Koehler se woordeboek nie prysgegee is nie. In 1956, 'n paar jaar nadat die KBL verskyn het, is Koehler dood. Professor W Baumgartner, wat die Aramese deel van die woordeboek saamgestel het, het toe begin om albei dele van die woordeboek te hersien, in samewerking met professore B Hartmann en EY Kutscher. Hierdie hersiene uitgawe het begin verskyn in 1967 in staan bekend as die derde uitgawe. In 1958 het 'n supplement verskyn waarin ook korreksies op die eerste uitgawe aangebring is. Tegelykertyd is die eerste uitgawe weer net so herdruk en hierdie twee dele saam word die 
tweede uitgawe genoem. In 1970 is ook Baumgartner dood, en kort daarna ook Kutscher in 1972. Drie dele van die hersiene uitgawe het reeds verskyn, tot by die inskrywing $r \bar{a}^{3} \bar{a}$. Die slotgedeelte oor die Bybelse Hebreeus en die hele Aramese woordeboek moet dus nog in hersiene vorm verskyn.

In die inleiding wat Baumgartner by die Aramese deel van die woordeboek geskryf het, het hy 'n kort uiteensetting van die geskiedenis van die Bybels-Aramese leksikografie gegee, verder ook'n opsomming en ' $n$ kort bespreking van die buite-Bybelse vergelykende Aramese materiaal. Vandag word die afsonderlike behandeling van die Aramese woordeskat van die $\mathrm{Ou}$ Testament as iets vanselfsprekends aanvaar. Baumgartner in die Supplementum (bl 128), verwys na die feit dat die verdeling van die woordeboek in ' $n$ Hebreeuse en Aramese deel deur verskillende sestiende- en sewentiende-eeuse geleerdes toegepas is. Johannes Cocceius was die eerste geleerde wat die Hebreeuse en Aramese woorde apart in een en dieselfde volume behandel het, en wel in die jaar 1669. Later is hierdie gebruik laat vaar. Dit was ook nie die geval in die eerste elf uitgawes van die woordeboek van Gesenius nie, waarin Chaldean, soos Aramees toe genoem is, langs die Hebreeuse woorde in alfabetiese volgorde ingeskryf is, en dit was eers in die eerste heruitgawe deur Frants Buhl van 1895, wat die twaalfde uitgawe van GB was dat die twee dele van mekaar geskei is. In die BDB-woordeboek wat in 1891 begin verskyn het, is die beginsel van skeiding van die begin af ingevoer. Op hierdie wyse het daar reg geskied aan die afsonderlike aard van die Aramese woordeskat. ' $n$ Mens moet egter volledig begrip hê daarvoor dat 'n enkele corpus wel saam behandel kon word, sonder dat daar tussen die verskillende tale waarin dit geskryf is onderskeid gemaak word. Dit is tewens die geval met die Talmoed tot op die huidige dag. As ' $n$ mens die bekende woordeboek van Jastrow ter hand neem, dan tref ' $n$ mens by alle inskrywings Hebreeus eerste, gevolg deur Aramees, in soverre as wat albei in die Talmoed voorkom, alfabeties langs mekaar aan. Alhoewel die Misjnagedeelte meestal uit Hebreeus bestaan, en die Gemara-gedeelte hoofsaaklik uit Aramees, is daar ook baie gemengde tekste in albei afdelings. As die Hebreeuse en Aramese woordeskat van die Talmoed dus in twee aparte woordeboeke gevind sou moes word, sou dit die gevolg hê dat elkeen wat die Talmoed lees van twee woordeboeke gebruik sou moes maak. Sover dit die Aramese tekste van die Bybel aangaan, is dit egter geen probleem nie, omdat die Aramese tekste en daarom die Aramese woordeskat in aaneenlopende passasies voorkom, te wete in 
Daniël 2:4b-7:28 en in Esra 4:11-6:18 en weer in 7:12-26. Verder kom daar wel enkele Aramese woorde voor in Genesis 31:47 en Jeremia 10:11. As 'n mens uit 'n praktiese hoek daarna kyk, bestaan die hele Bybels-Aramese woordeskat uit 650 woorde, waarby 40 eiename gevoeg moet word, en as hierdie woordeskat opgeneem sou word tussen die Hebreeuse woordeskat, sou dit in die massa verdwyn en die karakteristieke aard daarvan sou nie opgemerk kon word nie. Baumgartner het gewys op die belang van die ryk vergelykende Aramese materiaal vir wat hy noem 'the progress of etymology and semasiology'. Die verband wat daar bestaan tussen die Aramese woorde van die Bybel en die vele ander buite-Bybelse Aramese tekste kan die beste in ' $n$ aparte Aramese woordeboek behandel word.

Daar is nie ' $n$ wesenlike verskil tussen die eerste en die derde uitgawe van KBL nie. Formeel gesproke is al die woorde uit tale wat in 'n vreemde skrif geskryf word, met die uitsondering van Hebreeus (Aramees) en Grieks, getranskribeer. Die Engelse vertalings is weggelaat, die uitleg is verbeter en die verwysings na grammatika en tekste het vermeerder. Baumgartner het die belangrikste taak daarin gesien 'das Lexicon sprachwissenschaftlich und exegetisch auf der Höhe zu halten', hy wou met ander woorde die woordeboek taalkundig en eksegeties op datum bring. Baie nuwe materiaal is ingevoeg, variante uit die Orientaalse en Samaritaanse tekstradisies is bygevoeg, sowel as baie nuwe vergelykingsmateriaal. Die belangrikste hieronder is die na-Bybelse Hebreeus, byvoorbeeld die Hebreeuse teks van Sirag, die Qumran-tekste, en ook die Misjna en Midrasj. Die sogenaamde 'Mittelhebräisch' is versorg deur professor Kutscher van die Hebreeuse Universiteit in Jerusalem. Barr het die feit dat vroeër probeer is om die Bybelse Hebreeus van later Hebreeus te isoleer, altyd skerp gekritiseer (Barr 1973: 103): 'It is important even to know something about the distribution of a Middle Hebrew word (which occurs also in biblical Hebrew), about the type of context in which it occurs, about it productivity, etc. The importance of Middle Hebrew lies in the fact that it helps us to understand biblical Hebrew itself.' Dit gee 'n mens ' $n$ insig in die grense van die Bybelse Hebreeus, want ' $n$ mens kom te wete watter woorde teen die einde van die Bybelse periode toenemend gebruik is en watter op daardie tydstip alreeds besig was om uit te sterf. 'The meaning of a word in the post-biblical period can help us to estimate how far the traditions of its biblical meaning be genuine and go back to actual senses in usage, and how far on the other hand they derive from popular etymology, religious interpretation, and general 
guesswork' (Barr 1973: 112). Woordeboekinskrywings behoort nie slegs 'n aanduiding te gee oor wat met die Bybelse woord in later Hebreeus gebeur het nie, maar behoort ook die woorde te noem wat in die plek daarvan gekom het, soos byvoorbeeld niknas in die plek van $b \bar{o}^{3}$. Die werk van Kutscher was dus ' $n$ baie belangriker nuwe bydrae tot die leksikografie van die Ou Testament. Die woorde van Barr in hierdie verband verdien aandag: 'Post-biblical Hebrew (and Jewish Aramaic) is more than just one of the group of cognate languages, it is the linguistic medium through which biblical meanings were historically transmitted' (Barr 1968: 266). Dit is ondenkbaar dat daar in enige woordeboek in die toekoms nie ' $n$ groter integrasie van Bybelse en na-Bybelse Hebreeus op leksikografiese vlak sou plaasvind nie.

In die een en ' $n$ halwe dekade tussen die eerste en die derde uitgawes van $\mathrm{KBL}$ is daar ' $n$ magdom nuwe voorstelle vir Hebreeuse woorde gemaak, meestal gebaseer op die oorvloed van vergelykende materiaal wat beskikbaar geword het. Dit was veral as gevolg van die publikasie van tekste, taalkundige en eksegetiese werke en woordeboeke, soos byvoorbeeld die belangrike twee Akkadiese woordeboeke en een Mandese woordeboek wat verskyn het, asook vele werke op die terrein van Ugarities. 'n Beswaar wat teen die hantering deur Baumgartner van hierdie nuwe voorstelle ingebring kan word, is dat hy nie krities genoeg opgetree het nie. Barr het in hierdie opsig vier katagorieë voorgestel wat strek vanaf woorde wat 'n aparte inskrywing geregverdig het, omdat die identifikasie daarvan seker was, tot by 'n blote verwysing na ' $n$ bron waarin ' $n$ ander opinie gevind kon word (Barr 1968:262). Vanselfsprekend het die baie voorstelle vir nuwe identifikasies van woorde daartoe bygedra dat die aanduiding 'unerklärt' ('unexplained') baie minder voorkom in die nuwe uitgawe. Daar is egter ook 'n ander rede wat hiervoor verantwoordelik is, naamlik 'n nuwe houding teenoor die teks, 'n neiging om tekswysigings te vermy, en om eerder taalkundige verklaring aan te wend. Dit is ' $n$ goeie benadering, mits daaragter nie die sienswyse skuil dat die konsonante-teks onfeilbaar is en dat 'n mens maar vrylik aan die vokalisasie sou kon verander nie.

Die manier waarop die etimologiese gegewens ingeskryf is, kan ook bevraagteken word. ' $n$ Mens kan tereg vra wat die doel is van ' $n$ blote lys van tale waarin ' $n$ bepaalde stam voorkom, in min of meer dieselfde betekenis. In plaas van ' $n$ lang lys van woorde wat min of meer eenders is, aan te gee, sou volstaan kon word met 'n aanduiding dat die woord algemeen Semities is, maar nie in hierdie of daardie taal voorkom nie. 
As 'n mens egter 'n woord wat in 'n verwante taal in 'n totaal verskillende betekenis voorkom, sou opgee, sou dit waardevol kon wees. Die aangee van die negatiewe getuienis sou dus van groot waarde kon wees. Dit is nie van betekenis of die etimologiese gegewens aan die begin van ' $n$ inskrywing of aan die einde van ' $n$ inskrywing in ' $n$ woordeboek gegee sou word nie. Dit is wel problematies as dit aan die begin gegee word, en ' $n$ mens sou uit die betekenis van die woord moes aflei dat hierdie etimologieë eenvoudig gebruik is om by ' $n$ 'Grundbedeutung' of grondbetekenis uit te kom as betekenis van die gelyste woord. Teenoor hierdie verkeerde gebruik van die etimologie staan daar die juiste gebruik: Dit is die prosedure waarvolgens ' $n$ mens woorde uit verwante tale gebruik om die betekenis van 'n obskure Hebreeuse woord te probeer vasstel.

'n Bespreking van die prinsipes waarvolgens die verskillende betekenisse by die inskrywings van die stamme of woorde gerangskik is, sou ons hier te ver voer.

Dit is duidelik dat ons in die Hebreeuse leksikografie nog bly vassteek het by inskrywings volgens sintaktiese kenmerke. Onder 'n bepaalde stam word dan ses of sewe sogenaamde betekenisse gelys. Heel dikwels is twee of drie van daardie betekenisse presies eenders, maar in die een geval is dit sonder voorsetsel en in die ander geval met voorsetsel of met ' $n$ bywoord. Soms verskil die woordekwivalente wat aangegee word, maar dan het ons daar tog nie met verskillende betekenisse te doen nie, maar eenvoudig met verskillende ekwivalente vir dieselfde betekenis.

Met hierdie voëlvlug oor die Hebreeus-Ou-Testamentiese leksikografie het ons eindelik by ons eie dag aangekom. Dit was 'n pad van tien eeue van die eerste woordelys af tot by ' $n$ uitvoerige woordeboek bestaande uit verskillende bande in die 20 ste eeu, bande vol linguistiese, vergelykend-Semitiese en ensiklopediese gegewens. Soos woordelys en grammatika saam begin het, is hulle vandag nog saam. Woordelys as 'genre' het tot vandag nie sy aktualiteit en bestaansreg verloor nie. Van elke praktiese grammatika of spraakkuns, soos dié van B Gemser wat die eerste Hebreeuse spraakkuns in Afrikaans was, bly die Hebreeuse woordelys ' $n$ onontbeerlike bestanddeel. Dit is bedoel as ' $n$ praktiese hulpmiddel by die vertaling van geselekteerde, meesal eenvoudige en vereenvoudigde sinne uit die Ou Testament. Dit bemiddel 'n eerste kennismaking met die Ou-Testamentiese woordeskat wat niks van die kompleksiteit en die problematiek van die Hebreeuse leksikografie verraai nie. 'n Ander legitieme funksie van 'n woordelys in die huidige dag wat grootliks met die grammatika saamhang, is 
frekwensie-woordelyste wat 'n mens met die sogenaamde kernwoordeskat van ' $n$ corpus of taal in aanraking bring. Dit dien ' $n$ nuttige doel vir die skrywe van 'n grammatika om sinvolle keuses vir patroonsinne en oefeninge te maak.

Sover dit woordeboeke betref, het die 20 ste eeu 'n ryke verskeidenheid beleef. Naas die heruitgawe van $G B$ en die verskyning van die daaraan verwante $B D B$, wat egter op verskillende punte sy eie pad gegaan het, het daar in 1954 in Rome die Lexicon Hebraicum et Aramaicum Veteris Testamenti van $F$ Zorell en $L$ Semkowski verskyn. ' $n$ Hebreeus-Latynse woordeboek in die 20ste eeu maak ongelukkig die indruk van ' $n$ herlewing van die Middeleeue, veral as daar soms ook van Duitse vertaalekwivalente gebruik gemaak moet word om vir die leser te sê wat nou eintlik met die Latynse vertaalekwivalent bedoel word. Die KBL sal stellig, na die groot verbeterings in die derde uitgawe, die standaardwerk vir die res van die 20ste eeu bly. Volledigheidshalwe word hier net verwys na die historiese woordeboek wat verwysings na die Hebreeus van alle tye, van die vroegste af tot die moderne, insluit, waarmee die Akademie vir die Hebreeuse Taal in Jerusalem pas begin het. Dit is in moderne Hebreeus geskrywe en daar het nog net 'n specimen pamphlet: The root ' $r b$ verskyn in die tydskrif Lešonénu (1982).

Naas die gewone 'taalwoordeboeke' het die 20ste eeu egter ook die koms van sogenaamde teologiese woordeboeke begroet, eerstens op die Nuwe Testament (ThWNT) van Kittel-Friedrich en vervolgens 'n teologiese handwoordeboek op die Ou Testament (THAT) van E Jenni en G Westermann (Band I 1971, Band II 1976) en die Theologisches Wörterbuch zum Alten Testament (ThWAT) onder redaksie van GJ Botterweck en Helmer Ringgren (Band I 1973, Band II 1977 en Band III 1982 tot by die inskrywing $y$ tr). Ons gaan nie in op die kwessie van die beginsels wat ten grondslag lê aan die seleksie of weglating van terme nie, of die kriteria waarvolgens bepaal is of ' $n$ term ' $n$ teologiese konnotasie het of nie. Barr het hom die skerpste teen hierdie soort woordeboek uitgespreek, veral teen die manier waarop met 'betekenis' omgegaan word asof dit in enkele woorde geleë sou wees (Barr 1961: $206 \mathrm{vv;} \mathrm{1973:}$ $124 \mathrm{v} ; 1976$ : 186-190). Uiteraard is sulke woordeboeke, hoe groter hulle is, ensiklopedies van aard en sommige artikels wek die indruk dat hulle bedoel is vir een of ander ensiklopedie van die Oud-Oosterse kultuur- of godsdiensgeskiedenis. Soms, soos by die inskrywing ytr in ThWAT, soek 'n mens tevergeefs na enige teologiese relevansie. In die later aflewerings blyk dit of die kritiek sommige van die outeurs sover 
gebring het om rekening te hou met ander $\mathrm{Ou}$-Testamentiese woorde uit dieselfde semantiese sfeer. Die probleem is egter dat selfs in so 'n geval die verwante terme net genoem word, en nie bespreek word nie, met ander woorde, nie gekontrasteer word met die een in die woordeboekinskrywing nie. Die kritiese vraag wat Barr stel, is of die geweldige omvang en koste om sulke woordeboeke te produseer geregverdig is in die lig van die nut wat daaruit geput kan word. Sover dit die $\mathrm{Ou}$ Testament aangaan, blyk dit wel nuttig te wees omdat dit die $\mathrm{Ou}$ Testament duidelik in sy Oud-Oosterse omgewing plaas en daarteen kontrasteer, maar Barr vra: Is dit die inset werd?

Soos daar in die verlede ' $n$ behoefte was om die bestudering van ' $n$ bepaalde semantiese veld te onderneem, byvoorbeeld van die Bybelse woorde vir tyd (Barr 1962), sal geleerdes ook in die toekoms hulle toelê om 'n studie van 'n dergelike afgebakende eenheid wat 'n groep woorde vorm op grond van die feit dat hulle bepaalde linguisties-semantiese kenmerke in gemeen het. Dit is alles belangrike grondwerk vir 'n woordeboek wat met semantiese velde opereer. Hoe essensieel sulke studies ook al is, tensy daar op sistematiese wyse die hele OuTestamentiese leksikon (woordeskat) op 'n streng linguistiese grondslag deurgewerk word, sal 'n semantiese woordeboek nie tot stand kom nie.

$\mathrm{Na}$ arbeid van sestien jaar is daar tans ' $\mathrm{n}$ Griekse Semantiese Woordeboek in die publikasieproses. Dit is 'n projek van die United Bible Societies en die Bybelgenootskap van Suid-Afrika waarvan die bekende professor Eugene Nida die inisieerder was en waarin professor JP Louw van die Departement Grieks van die Universiteit van Pretoria 'n leeue-aandeel gehad het. Ter voorbereiding van 'n dergelike projek vir die Ou Testament is daar in Januarie 1983 'n twee-week-lange seminaar in Bybelhuis, Kaapstad, gehou waaraan proff Nida en Louw, Jan de Waard van Straatsburg, die skrywer van hierdie artikel en verskillende verteenwoordigers van die Universiteit van Pretoria, Universiteit van Suid-Afrika, Randse Afrikaanse Universiteit, Universiteit van die Oranje-Vrystaat, Universiteit van Stellenbosch en die Universiteit van Wes-Kaapland deelgeneem het. Die komitee wat so tot stand gekom het, het intussen op gereelde tye weer bymekaargekom om die voorbereidingswerk wat aan die verskillende universiteite gedoen is, te bespreek. Prof Louw tree namens die Bybelgenootskap op as koördineerder van hierdie projek en die skrywer van hierdie artikel as voorsitter van die Suid-Afrikaanse Komitee. Aan die Universiteit van Pretoria is tans die volgende persone by die projek ingeskakel: Naas proff 
Louw en Van Wyk, mnre JH Potgieter en PJ Botha van die Departement Semitiese Tale, asook junior dosente van die Departement Grieks en Semitiese Tale, wat tans bestaan uit mnre JA Bosman, GJ Lindeque, JM Strydom (Grieks) en WC van Wyk jr.

Daar lê 'n lang pad voor. Waardevolle ondervinding wat met die Nuwe-Testamentiese projek opgedoen is, staan tot die beskikking van die medewerkers aan die Ou Testament-projek. Maar die Hebreeuse taal en woordeskat stel ook eiesoortige eise en lewer probleme op waarvoor bevredigende oplossings gevind sal moet word, binne die raamwerk van 'n stelsel van semantiese komponente-analise en definisie, byvoorbeeld die hantering van die stelsel van grond- en afgeleide stamme (G-, D- en H-stamme), en van sogenaamde homofone wat dieselfde skrifbeeld vertoon maar foneties gesproke 'n verskillende herkoms het. Daar moet vir hierdie werk van vooraf begin word. Elke woord en stam moet deur middel van die konkordansie volledig op elke plek waar dit voorkom in konteks nagegaan word om die verskillende betekenisse daarvan te bepaal. Eers as dit gedoen is, kan tot 'n klassifikasie in semantiese velde en tot ' $n$ kontrastering van die verskillende terme binne dieselfde semantiese veld oorgegaan word deur middel van noukeurige komponente-analise. Weergee van vertaalekwivalente is nie voldoende nie, want verskillende wourde kan gebruik word om dieselfde betekenis weer te gee. So is in bepaalde kontekste woorde soos 'verdelg', 'vernietig', 'uitroei' nie verskillende betekenisse nie, maar verskillende woorde waarmee een en dieselfde betekenis uitgedruk word. Besondere aandag sal ook daaraan geskenk moet word om die 'suiwer'-linguistiese betekenis van die woorde te bepaal. Enkele voorbeelde sal voldoende wees: vir $q$ t $n$ word naas 'klein wees', 'n betekenis, 'te klein wees' aangegee. Die 'te' in 'te klein wees' kom egter eers te sprake as daar die voorsetsel min bykom, met ander woorde, op grond van die voorsetsel word 'te klein wees' as betekenis aangegee. Daar moet egter gevra word: Wat dra die woord $q t n$ alleen by tot die betekenis? Daarvolgens beteken dit net: 'klein wees'. As 'n woordeboek onder yōm naas die betekenis 'dag' ook 'vandag' aangee, op grond van die uitdrukking 'tot op hierdie dag', dan is dit verkeerd, want in so 'n vertaling is 'hierdie' bygereken, 'dag' (yōm) is hier maar net 'tydstip, era'.

'n Slotopmerking: 'n Mens moet nie aan die illusie ly dat 'n nuwe woordeboek, al sou dit suiwer-wetenskaplik die bogenoemde twee faktore in berekening bring, te wete linguistiese betekenis en semantiese velde, aan alle behoeftes aan ' $n$ woordeboek van die Ou Testa- 
ment sou voldoen nie. 'n Bepaalde woordelys of woordeboek van watter slag dit ook al mag wees, filologies-sintakties, teologies of linguisties, beantwoord aan spesifieke behoeftes. 'n Mens mag uit verskillende oogpunte redeneer oor die legitimiteit van bepaalde behoeftes, maar dié behoeftes mag almal bevredig word solank dit op 'n wetenskaplik-verantwoordbare wyse sal geskied, met duidelike kriteria vir seleksie en ordening van terme en 'betekenisse'.

\section{Literatuurverwysings}

BARR, J 1962. Biblical Words for Time. London.

BARR, J 1973. Hebrew Lexicography, in Pelio Fronzaroli, Studies in Semitic Lexicography. Florence, 103-126.

BARR, J 1976. The nature and purpose of a theological dictionary. Interpretation XXX, $186-190$.

JONES, DR 1963. Lexicography, in SL Greenslade (ed), The Cambridge History of the Bible. Part 3. Cambridge: CUP.

KOEHLER, L 1953. Lexicon in Veteris Testamenti Libros, Leiden: Brill.

WAXMAN, M 1960. A History of lewish Literature. Volume I. New York: Bloch. 